\section{The Impact of Private Equity and Venture Capital Funds on post-IPO Operational and Financial Performance in Brazilian invested companies}

\author{
Bianca Piloto Sincerre ${ }^{1,+(1)}$ \\ ${ }^{1}$ Fundação Getulio Vargas Escola de Administração de Empresas de São Paulo, São Paulo, SP, Braz̧il \\ Joelson Sampaio $2, \Omega$ (iD \\ ${ }^{2}$ Fundação Getulio Vargas Escola de Economia de São Paulo e FECAP, São Paulo, SP, Brazil \\ Rubéns Famá ${ }^{3, \mp}$ (1) \\ ${ }^{3}$ FECAP, São Paulo, SP, Brazil \\ Eduardo $S$ Flores ${ }^{4 *} *$ (1) \\ ${ }^{4}$ Universidade de São Paulo e Fundação Getulio Vargas, São Paulo, SP, Braẓil
}

\begin{abstract}
The present article seeks to analyze the legacy and its persistence over time in terms of financing and operational policies and financial performance, of companies invested by Private Equity and Venture Capital funds (PE/VC). The PE/VC industry is characterized by the function of identifying companies with large return potentials and that grow arithmetically - due to capital constraints - to provide adequate and necessary sources of capital and experience for exponential growth. In this study, we used four measures that relate to companies' financial policies and their persistence over time: i) cash \& equivalents; ii) leverage; iii) Return on Assets (ROA); and iv) sales growth. The results suggest that PE / VC invested companies imply higher levels of cash \& equivalents and are associated with a lower level of leverage during the first 5 years after the IPO. In addition, companies financed by PE/VC funds show higher profitability and higher sales growth compared to non-invested companies in the short term, i.e., in the first 3 years after the IPO.
\end{abstract}

Keywords: Venture Capital; Operational Performance; Financial Performance; Initial Public Offering of Shares.

\section{INTRODUCTION}

Venture capital funds, commonly known as Venture Capital and Private Equity (PE/VC), seek emerging companies that have competitive advantages and are inserted in fast-growing markets. The function of these funds is precisely to identify companies that grow arithmetically - due to capital constraints - to provide adequate and necessary sources of capital and experience for the exponential growth of these companies. PE/VC funds represent a viable alternative to traditional financing, because they are financial agents well adapted to mitigate the characteristic risks associated with the companies that invest. In addition, PE/VC funds adopt differentiated governance and monitoring practices (SAHLMAN, 1990).

The development of the PE/VC industry began in the United States, in which companies such as Microsoft, Compaq, Apple, Sun, Amazon, Lotus, Cisco, Staples, Federal Express and Netscape were invested by $\mathrm{PE} / \mathrm{VC}$ funds and formed completely new industrial segments. When

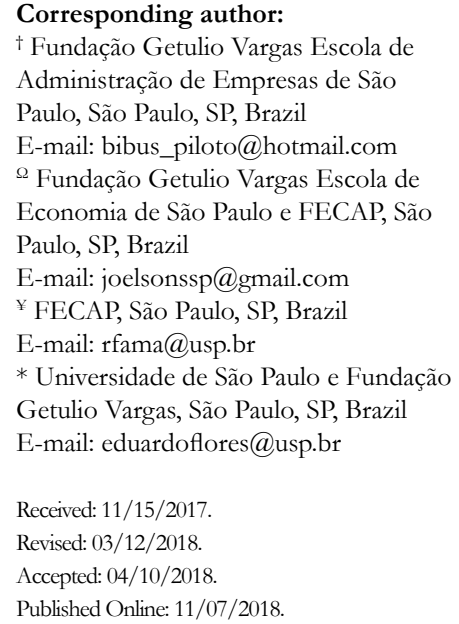


analyzing the American stock market, about $30 \%$ of companies listed on the stock exchange between 1991 and 1997, had received resources from PE/VC. These companies constituted about $20 \%$ of the total value of these emissions (GOMPERS and LERNER, 1999).

According to Kreps (1990) and Hermalin (2001), corporate culture is important to understanding the company's strategic choices and financial performance. Corporate culture can be defined as a specific set of norms, beliefs, values, and preferences that are shared between executives and workers. Therefore, company culture can be fundamental in its strategic choices, because it defines an "aligned" behavioral profile when their managers are faced with unforeseen contingencies or multiple equilibria (KREPS, 1990).

In this context, the present article seeks to analyze the legacy and its persistence over time in terms of financing policies and financial performance, of companies invested by PE/ VC funds. We used four measures similar to those by authors Cronqvist, Low and Nilsson (2009) which relate to companies' financial policies and their persistence over time: i) cash \& equivalents; ii) leverage; iii) Return on Assets (ROA); and iv) sales growth. The analysis seeks to verify the legacy, in terms of culture of financing policy and performance, which the PE/VC funds leave in the companies invested after the IPO.

The results show that companies financed by PE/VC funds have a higher level of cash \& equivalents in the first 5 years after the IPO. This result can be explained in parts by the fact that these companies are generally new and with high potential for growth. In this sense, the high level of cash \& equivalents may reflect the choice to distribute less dividends and reinvest capital in new opportunities.

Under the same rationale, companies invested in $\mathrm{PE} / \mathrm{VC}$ funds have a lower leverage ratio in the first 5 years after the IPO, in comparison with those not financed by PE/VC. These companies, in addition to having more capital options, must return to the PE/VC funds the investments made by them. Carvalho et al. (2013) show that $25 \%$ of the exit from investment of PE/VC funds between 2004 and 2009 were through IPO. In this sense, companies invested by $\mathrm{PE} / \mathrm{VC}$ are more likely to issue shares instead of debt.

The present study also found evidence that companies financed by $\mathrm{PE} / \mathrm{VC}$ have a higher level of profitability - as measured by ROA - in the short term, i.e., in the first three years after the IPO. In the same direction, companies financed by PE/VC show a higher level of sales growth in the first 3 years after the IPO.

The paper is structured as follows: section 1 begins with the introduction; section 2 presents the literature, seeking to highlight the main studies related to PE/VC found in Brazil and in other countries. The methodology and sample, as well as the application of the proposed models, can be found in section 3. Following, we present the results and their implications in section 4 . Final considerations conclude the study.

\section{LITERATURE REVIEW AND HYPOTHESES DEVELOP- MENT}

The Private Equity and Venture Capital industry provides capital for companies with high return potential. From the perspective of the authors Gompers and Lerner (2001), to understand the $\mathrm{PE} / \mathrm{VC}$ industry, it is paramount to understand the entire risk cycle, in which it consists basically of four phases: raising funds, investment, monitoring and output. The cycle begins with the survey of the risk fund, the prospection and selection of the proposals through analysis of the projects. In the monitoring phase, it is verified whether the expected results are being achieved; there is also added value as a consequence of shared management. The cycle ends when PE/VC funds are able to return capital to shareholders by exit mechanisms, and it is renewed when those funds raise additional resources to be reinvested. 
Often, the Initial Public Offerings (IPO) is not exclusively the output of the investor of PE/ $\mathrm{VC}$ from investees, but rather a mechanism for obtaining funds to finance its expansion. Venture capital investors keep their shares for years after the IPO (BARRY et al., 1990). Therefore, $\mathrm{PE} / \mathrm{VC}$ investors have incentives to put in place governance systems to preserve the value of their investment.

There is a broad theoretical field that suggests that the PE/VC industry contributes significantly to the success of start-up companies. PE/VC funds are typically active investors who try to add value through their participation in business management. In addition, the skills of PE/VC funds in tracking and monitoring investees can help in the operational performance of these companies (BARRY et al., 1990).

Brav and Gompers (1997) state three reasons why PE/VC funded enterprises in the IPO period may differ from non-funded firms. Firstly, PE/VC funds implement a management structure that assists in the operational performance of companies. In addition, they can use their knowledge in the industry to improve the company's operations, providing valuable information on capital increase. Secondly, $\mathrm{PE} / \mathrm{VC}$ funds may affect who owns the shares of companies after the IPO. Large investors will acquire shares of companies due to $\mathrm{PE} / \mathrm{VC}$ funds having contacts with large investment banks. These relationships can lead to future relationships after the IPO. Finally, PE/VC funds hold positions in the board of directors of start-ups and maintain them even after the IPO. The advantage is that these advisors have experiences that can improve the management of these companies, in addition to facilitating the financing.

$\mathrm{PE} / \mathrm{VC}$ funds play separate roles in companies. They are direct funders and monitor business operations indirectly (PHILIPS, 1991). In addition, they are often considered strategic investors, and their involvement with corporate strategies is a key value-added activity for these companies (FRIED; BRUTON; HISRICH, 1998).

Overall, $\mathrm{PE} / \mathrm{VC}$ funds are looking for risky young companies with high growth potential, in which they have high expectations of production of innovative products and services. Thus, these funds tend to make their investments at an early stage of business development, when the prospect of success is far from being achieved. PE/VC funds therefore play an influential and relevant role in the strategic evolution of the investees and in their investment and financing decisions. Therefore, companies financed by PE/VC may be more likely to issue shares than debt, since there would be more sources of capital \& equivalents. Consequently, they would have lower levels of leverage compared to companies not financed by PE/VC.

Life cycle theories provide theoretical background to investigate the relationship between PE/VC involvement and the level of cash \& equivalents after the IPO. The life cycle theory suggests that dividends are usually paid by mature, established and profitable firms with low growth prospects, while the retention of profits is chosen by younger, high-growth companies with large investment opportunities and limited resources (DEANGELO et al, 2006). Thus, according to the life cycle theory, companies financed by PE/VC, typically young and with high-growth (LERNER, 1994), are more likely to maintain higher cash levels after the IPO.

Kaplan and Stromberg (2003) evince that venture capital investors impose complex control rights when investing in a company, and put in place strong mechanisms of governance and monitoring.

Hellmann and Puri (2002) emphasize that the investments of PE/VC are related to several measures of professionalization, such as the adoption of a stock option program and the reformulation of human resources policies. The authors also note that start-up companies 
invested by $\mathrm{PE} / \mathrm{VC}$ replace the founder of the company more quickly and more frequently by an external Chief Executive Officer.

In Brazil, Siqueira, Carvalho and Netto (2011) investigate the determinants of the success of PE/VC investments, using data from the period from 1999 to 2007. The authors emphasize that the factors influencing the performance of investment vehicles are: volume of capital committed, number of investments made, existence of co-investments, foreign origin and experience of the management organization, focus on private equity firms, intensity of contact between managers and portfolio companies and the number of seats on boards of directors of companies invested by fund manager. Therefore, the success of PE/VC investments depends on the characteristics of the funds, how the investments are structured and the management style of the investments.

Minardi, Kanitz and Bassani (2014) investigate the Brazilian performance of private equity and venture capital between 1990 and 2013. The authors conclude that, although Brazilian PE and VC industries are young, players are slow to mature, with $72 \%$ of companies operating for 5 years or more. The industry has performed well over the last 20 years, compensating for international Limited Partnerships (LPs) to invest in Brazil. In addition, Brazilian PE/VC funds outpaced US funds between 1990 and 2008. Therefore, international investors were remunerated for assuming the country risk in Brazil. The authors emphasize that there are three explanations for this good performance: i) the Brazilian economic boom between 2004 and 2012; ii) the limited competition for business in Brazil at that time; and iii) the fact that PE/VC managers in Brazil are becoming more experienced, leading the company to better performance.

Lastly, Carvalho, Pinheiro and Sampaio (2015) analyzed the role of VCs in terms of corporate financial policy and the persistence of (fixed effects of the company) companies invested by $\mathrm{PE} / \mathrm{VC}$ over time. The main conclusion was that the origin of a joint venture leads to similarities in company policies over a period of time after the IPO. Companies invested by PE/VC choose a different set of policies from companies not invested by PE/VC. The authors found evidence that companies invested by PE/VC imply a higher level of cash reserves than non-invested companies. This effect is permanent for at least 8 years after the IPO. In addition, the authors showed that $\mathrm{PE} / \mathrm{VC}$ invested companies are associated with lower level of leverage and interest coverage during the first 8 years after IPO.

\subsection{HYPOTHESES}

Companies that distribute much of their income in the form of dividends are less likely to accumulate cash on their balance sheets, or they feel obliged to spend on marginal acquisitions or investments. Jain, Shekhar and Torbey (2009) show that companies invested by $\mathrm{PE} / \mathrm{VC}$ are young and growing companies, so these companies tend to distribute less dividends from their earnings.

In addition, as funders, PE/VC often oversee managerial decisions (CARPENTER et al., 2003; VAN DER BERGHE and LEVRAU, 2002). The hypothesis of alignment of interests suggests that the existence of large shareholders improves the protection of minority shareholders, leading to a positive effect of the presence of PE/VC on cash $\&$ equivalents. Chen and Chuang (2009) emphasized the relationship between Venture Capitalists (VCs) and the impact on cash \& equivalents. According to the authors, the hypothesis of alignment of interest suggests that shareholders are more likely to accept large cash reserves to finance new investment projects.

In the case of the Brazilian capital market, the obligation to distribute dividends is provided for in articles 202 to 205 of the Law 6,404 of 1976, known as public companies law (ARAÚJO, 1996). In accordance with the provisions of Article 202, such 
BBR

16,1

91

companies must distribute at least $25 \%$ of adjusted net income, when the status of the corporation is omitted. However, there may be situations where the statute establishes values below this threshold ${ }^{1}$, which in practice causes a permutative set about how Brazilian companies will pay dividends to their shareholders. In this context, the presence of risk investors may have a positive effect on cash \& equivalents of investees in the years preceding the IPO as such investors taking advantage of Article 202 of the (S.A) Corporation Law, can reduce the percentage of dividends paid resulting in greater retention of cash and cash \& equivalents. Given this context, the first hypothesis can be formulated as follows:

Hypothesis 1: Companies financed by $P E / V C$ have higher levels of cash \& equivalents after the IPO compared to those not financed by $P E / V C$.

The second objective of the article is to analyze how the presence of PE/VC funds affects the financial structure of the company in the coming years after the IPO. These funds can play an important role in the transmission of the intrinsic value of the companies invested to the financial market, thereby reducing the degree of information asymmetry. The reduction of information asymmetry, in turn, may influence various aspects of the company's financial policy (see, for example, Myers and Majluf (1984)). Singularly, this implies that companies financed by PE/VC may be more likely to issue shares (since they are more likely to get a fair price for their stock), so they will have lower levels of leverage. Thus, if PE/VC funds are able to prove the intrinsic value of invested companies and thus reduce the degree of information asymmetry, the companies financed by $\mathrm{PE} / \mathrm{VC}$ will be associated with lower leverage ratios. Therefore, we formulate the second hypothesis as follows:

Hypothesis 2: Companies financed by $P E / V C$ have lower leverage levels after the IPO compared to those not financed by $P E / V C$.

With regard to the ROA variable, Morsfield and Tan (2006) argue that companies invested by PE/VC funds tend to have on average, better performance in their investments when compared to those not invested by PE/VC. Therefore, we formulate the third hypothesis as follows:

Hypothesis 3: Companies financed by $P E / V C$ show higher levels of profitability after the IPO compared to those not financed by $P E / V C$.

Finally, another way of measuring the operational performance of companies is through their sales performance. Regarding the variable sales growth, Puri and Zarutskie (2012) report that PE/VC-funded firms grow faster in terms of sales than non-funded firms do. This result is persistent mainly in the early years, before the stabilization of growth.

The studies conducted by Paglia and Harjoto (2014) also show that companies financed by $\mathrm{PE} / \mathrm{VC}$ have a positive impact on sales growth. The authors state that this result persists for three consecutive years after the start of the investments made by the PE/VC funds. Additionally, Chemmanur et al. (2011) show that the total efficiency gains generated by $\mathrm{PE} / \mathrm{VC}$ come mainly from a high sales growth in the years following the receipt of venture capital. Therefore, we can formulate the fourth hypothesis as follows:

Hypothesis 4: Companies financed by $P E / V C$ show higher levels of sales growth after the IPO compared to those not financed by PE/VC.

\section{METHODOLOGY}

In the present study, we used four measures for the company's financial policy: i) cash \& equivalents; ii) leverage; iii) Return on Assets (ROA); and iv) sales growth. These measures are based on Cronqvist, Low and Nilsson (2009).

\footnotetext{
${ }^{1}$ See, for example, the Notice of Shareholders of the OGX - OGX: Dividend payment (June 23, 2009).
} 
The hypothesis of the proposed study refers to the difference between companies financed by $\mathrm{PE} / \mathrm{VC}$ and not financed by $\mathrm{PE} / \mathrm{VC}$ in terms of financial policy and its persistence. The equation that tests the four hypotheses can be defined as follows:

$$
\text { Dependent }_{i, t}=\beta_{0}+\beta_{1} P E / V C_{i}+y^{\prime} x_{i, t}^{\prime}+\theta^{\prime} \text { industry }_{i}+\tau_{t}+\mu_{i, t}
$$

Where:

Dependent $_{i}$ : are the four dependent variables: i) cash \& equivalents; ii) leverage; iii) ROA; and iv) sales growth;

$x_{i, t}^{\prime}:$ is a vector of predetermined characteristics of company $i$ in the year $t$ : Fixed Assets, technology dummy, IFRS dummy, earnings management, book value of assets, and sales growth. In situations in which one of these characteristics becomes a dependent variable, therefore, we do not insert it as an independent term.

We estimate the regressions specified in model 1 using Pooled OLS with sector dummy. We also used robust standard errors following White (1980) and cluster by industry.

\subsection{Database And Sample}

The sample is composed of accounting and market data of the companies listed on the São Paulo Stock Exchange, BM\&FBovespa (Bovespa). We explain the formation of each variable in Table 1. We obtained the data by means of a Bloomberg, L.P terminal, in which they are in real values of 2017, adjusted for accumulated period-to-period inflation using the broad IPCA. The period of IPOs, initially raised, was from January 2000 to December 2017, with annual data. As the study analyzes up to 5 years after the IPO, the cutoff period was 2012 so that we were able to analyze the years following the issuing of shares.

The sample consists of 150 companies, divided by 40 invested companies and 110 invested by PE/VC. In addition, it is composed only of companies that presented data for the 5 years of analysis of this article.

Table 1. Definition of Main Variable

\begin{tabular}{ll}
\hline Private Equity and Venture Capital (PE/VC) & $\begin{array}{l}\text { It is the dummy variable that takes value one for companies } \\
\text { financed by PE/VC, and zero otherwise; }\end{array}$ \\
\hline Cash \& Equivalents & $\begin{array}{l}\text { It is defined as cash and short-term investments divided by the } \\
\text { book value of the assets; }\end{array}$ \\
It is defined as the sum of short and long-term debt divided by the \\
book value of assets;
\end{tabular}


BBR 16,1

The information that part of these companies had in their shareholding bases PE and/ or VC funds, was done through the manual survey of stock issue prospectuses, disclosed during the IPO's.

Table 2 presents the descriptive statistics for the variables that characterize the heterogeneity of the companies. Initially, we can verify that for these variables, the invested companies by $\mathrm{PE} / \mathrm{VC}$ and the non-invested ones are very different. In terms of cash \& equivalents, for the PE/VC sample, the mean is $0.48 \mathrm{MM}$ BRL one year after the IPO, while for the non-PE/VC sample it is $0.33 \mathrm{MM} \mathrm{BRL}$. This difference persists for five years after the IPO, where the mean for PE/VC is $0.78 \mathrm{MM} \mathrm{BRL}$ and $0.42 \mathrm{MM}$ BRL for non PE/VC.

Table 2. Descriptive Statistics of Dependent and Control Variables

The values reported in this table are the means of each of the variables. In parentheses are the standard deviations. All accounting data is in real values for 2017, that is, they were adjusted for accumulated inflation from period to period using the broad IPCA index. In addition, the review period is from January 2000 to December 2017.

\begin{tabular}{|c|c|c|c|c|c|c|c|c|c|c|}
\hline \multirow[t]{2}{*}{ Years } & \multicolumn{2}{|c|}{$\begin{array}{c}\text { Funded by } \\
\text { PEVC }\end{array}$} & \multicolumn{2}{|c|}{$\begin{array}{c}\text { Funded by } \\
\text { PEVC }\end{array}$} & \multicolumn{2}{|c|}{$\begin{array}{c}\text { Funded by } \\
\text { PEVC }\end{array}$} & \multicolumn{2}{|c|}{$\begin{array}{c}\text { Funded by } \\
\text { PEVC }\end{array}$} & \multicolumn{2}{|c|}{$\begin{array}{c}5 \\
\text { Funded by } \\
\text { PEVC }\end{array}$} \\
\hline & Yes & No & Yes & No & Yes & No & Yes & No & Yes & No \\
\hline Cash & 0.48 & 0.33 & 0.58 & 0.36 & 0.64 & 0.31 & 0.75 & 0.42 & 0.78 & 0.42 \\
\hline & $(0.35)$ & $(0.36)$ & $(0.37)$ & $(0.43)$ & $(0.46)$ & $(0.42)$ & $(0.36)$ & $(0.43)$ & $(0.31)$ & $(0.43)$ \\
\hline Leverage & 0.14 & 0.42 & 0.17 & 0.42 & 0.34 & 0.43 & 0.41 & 0.45 & 0.52 & 0.44 \\
\hline & $(0.19)$ & $(0.79)$ & $(0.22)$ & $(0.75)$ & $(0.49)$ & $(0.80)$ & $(0.68)$ & $(0.83)$ & $(0.69)$ & $(0.76)$ \\
\hline ROA & 1.83 & 1.12 & 1.60 & 0.99 & 1.47 & 0.95 & 1.14 & 0.84 & 1.18 & 0.85 \\
\hline & $(1.43)$ & $(1.32)$ & $(1.33)$ & $(1.15)$ & (1.16) & $(1.14)$ & (1.13) & $(0.92)$ & (1.39) & $(0.95)$ \\
\hline Sales Growth & 0.15 & 0.13 & 0.15 & 0.08 & 0.17 & 0.06 & 0.050 & 0.08 & 0.05 & 0.09 \\
\hline & $(0.28)$ & $(0.23)$ & $(0.21)$ & $(0.24)$ & $(0.26)$ & $(0.29)$ & $(0.27)$ & $(0.29)$ & $(0.2)$ & $(0.27)$ \\
\hline Fixed Assets & 2.76 & 6.88 & 2.74 & 8.48 & 3.07 & 4.17 & 3.52 & 4.39 & 3.52 & 4.54 \\
\hline & $(1.59)$ & $(42.21)$ & (1.14) & $(52.21)$ & $(2.46)$ & (18.23) & $(0.73)$ & $(20.52)$ & $(0.78)$ & (20.71) \\
\hline Earnings Management & 3.30 & 5.20 & 2.15 & 4.27 & 2.07 & 3.52 & 2.52 & 3.41 & 2.52 & 3.74 \\
\hline & $(1.31)$ & $(2.32)$ & $(1.27)$ & $(2.01)$ & $(1.46)$ & $(2.41)$ & $(1.73)$ & (263) & $(1.78)$ & $(2.65)$ \\
\hline Size & 20.1 & 25.6 & 22.38 & 24.71 & 20.54 & 26.10 & 20.32 & 26.97 & 21.71 & 25.17 \\
\hline & $(0.88)$ & $(2.20)$ & $(0.71)$ & $(1.96)$ & $(0.99)$ & $(2.07)$ & $(1.02)$ & (1.99) & $(1.07)$ & (1.89) \\
\hline Technology Sector & 0.07 & 0.13 & 0.07 & 0.18 & 0.05 & 0.13 & 0.06 & 0.13 & 0.08 & 0.13 \\
\hline & $(0.24)$ & $(0.32)$ & $(0.22)$ & $(0.36)$ & $(0.26)$ & $(0.35)$ & $(0.25)$ & $(0.33)$ & $(0.33)$ & $(0.34)$ \\
\hline Observations & 40 & 110 & 40 & 110 & 40 & 110 & 40 & 110 & 40 & 110 \\
\hline
\end{tabular}

We can observe the same pattern for other variables, such as ROA and sales growth. However, for sales growth, the difference decreases over time and reverts 4 years after the IPO.

Regarding the level of leverage, invested and non-invested companies by PE/VC are also different. For the PE/VC sample, the mean for leverage is $14 \%$ one year after the IPO, whereas for the non-PE/VC sample, it is $42.0 \%$. This difference is persistent in the 5 years after the IPO. Similarly, we can observe a similar pattern for other variables such as fixed assets, size and companies in the technology sector.

The persistence of these differences can be understood, in parts, as a legacy (fixed effect) that PE/VC funds leave in invested companies. Cronqvist, Low and Nilsson (2009) evidence that the financing and investment policies of companies are persistent over time. In 
the same direction, we can observe in these results that the legacy of PE/VC funds tends to remain in invested companies even 5 years after the IPO.

\section{RESULTS}

In this section we present the results obtained with the estimations of the statistical models respectively oriented by the establishment of the hypotheses in section 3 .

\subsection{CaSh \& Equivalents}

In general, cash \& equivalents result from prudential reasons or limited access to external financing. In this article, we analyzed the factors that condition companies' cash and cash \& equivalents, and its persistence over time for companies financed and not financed by $\mathrm{PE} / \mathrm{VC}$.

Table 3 shows the results obtained. The companies invested by PE/VC, imply higher levels of cash, over the first five years after the IPO. In terms of company characteristics, large companies in terms of total assets and with higher fixed assets, implies higher levels of cash \& equivalents.

Table 3. Cash \& Equivalents

The dependent variable is cash \& equivalents from year 1 to year 5 after the IPO. The robust $\mathrm{t}$ (or $\mathrm{z}$ ) statistics on heteroscedasticity by White's (1980) method of correction are presented in parentheses.

\begin{tabular}{lccccc}
\hline Year & 1 & 2 & 3 & 4 & 5 \\
\hline VC dummy & $0.178^{* *}$ & $0.171^{* *}$ & $0.184 * *$ & $0.261^{* * *}$ & $0.300^{* * *}$ \\
Net & $(2.40)$ & $(2.04)$ & $(2.27)$ & $(3.14)$ & $(3.19)$ \\
Fixed Assets & $-0.002^{* * *}$ & $-0.003^{* *}$ & $-0.002^{* * *}$ & $-0.001 * * *$ & -0.001 \\
Size & $(-2.71)$ & $(-2.32)$ & $(-2.83)$ & $(-2.80)$ & $(-1.25)$ \\
& $0.173^{* * *}$ & $0.156^{* * *}$ & $0.156^{* * *}$ & $0.121^{* * *}$ & $0.132^{* * *}$ \\
Sales & $(14.79)$ & $(9.40)$ & $(10.11)$ & $(5.10)$ & $(4.95)$ \\
Growth & 0.104 & -0.019 & 0.004 & $0.265^{*}$ & 0.182 \\
Earnings & $(0.97)$ & $(-0.14)$ & $(0.04)$ & $(1.87)$ & $(0.99)$ \\
Management & 0.001 & 0.001 & 0.012 & 0.001 & -0.001 \\
Technology Sector & $(1.47)$ & $(1.02)$ & $(1.03)$ & $(0.68)$ & $(-0.09)$ \\
& 0.132 & -0.009 & -0.034 & -0.044 & 0.026 \\
IFRS dummy & $(1.16)$ & $(-0.10)$ & $(-0.37)$ & $(-0.40)$ & $(0.22)$ \\
& $0.202 * * *$ & $0.150 * *$ & 0.120 & 0.054 & 0.041 \\
\hline Sector dummy (SIC-2) & $(4.07)$ & $(2.59)$ & $(1.65)$ & $(0.59)$ & $(0.46)$ \\
Time dummy (year) & Yes & Yes & Yes & Yes & Yes \\
\hline Observations & 150 & Yes & Yes & Yes & Yes \\
R-squared & 0.436 & 0.465 & 0.485 & 0.490 & 150 \\
*, & Yes & 150 & 150 & 150 & 0.510 \\
\hline
\end{tabular}

The results we found are consistent with Chen and Chuang (2009), which highlight the relationship between the Venture Capitalists (VCs) and their positive impact on cash and cash \& equivalents. In addition, the results are also in line with Carvalho, Pinheiro and Sampaio (2015), that even by analyzing US companies, also found high levels of cash \& equivalents for companies financed by $\mathrm{PE} / \mathrm{VC}$. These results persist for at least 8 years after the IPO. 
The higher level of cash \& equivalents of the companies invested by PE/VC may be

BBR

16,1

95

related to the fact that these companies finance part of their growth with liquidity. As they have a significant need for working capital due to rapid growth that they present; therefore, higher cash levels can finance their operating activities without the need to resort to borrowing repeatedly.

\subsection{LEVERAGE}

Table 4 suggests that $\mathrm{PE} / \mathrm{VC}$ invested companies are associated with a lower level of leverage during the first 5 years after the IPO.

Table 4. Leverage

The dependent variable is the leverage of year 1 to year 5 after the IPO. The robust $\mathrm{t}$ (or z) statistics on heteroscedasticity by White's (1980) method of correction are presented in parentheses.

\begin{tabular}{lccccc}
\hline Year & 1 & 2 & 3 & 4 & 5 \\
VC dummy & $-0.365^{* * *}$ & $-0.313^{* * *}$ & $-0.236^{* * *}$ & $-0.221^{* *}$ & $-0.189 *$ \\
Net & $(-4.48)$ & $(-4.12)$ & $(-3.03)$ & $(-2.14)$ & $(-1.85)$ \\
Fixed Assets & 0.000 & 0.000 & $0.006^{* *}$ & $0.005^{* *}$ & $0.006^{* * *}$ \\
Size & $(0.17)$ & $(0.32)$ & $(2.37)$ & $(2.56)$ & $(2.69)$ \\
& $0.280 * * *$ & $0.249 * * *$ & $0.296^{* * *}$ & $0.324 * * *$ & $0.263 * * *$ \\
Sales & $(6.11)$ & $(4.89)$ & $(7.22)$ & $(7.89)$ & $(6.86)$ \\
Growth & 0.102 & -0.266 & -0.248 & 0.065 & -0.181 \\
Earnings & $(0.77)$ & $(-1.62)$ & $(-1.37)$ & $(0.33)$ & $(-0.87)$ \\
Management & $-0.001 *$ & -0.012 & -0.001 & $-0.011 * *$ & 0.000 \\
Technology Sector & $(-1.68)$ & $(-0.51)$ & $(-1.41)$ & $(-2.06)$ & $(1.29)$ \\
& -0.016 & $-0.129 *$ & 0.128 & 0.145 & 0.041 \\
IFRS dummy & $(-0.14)$ & $(-1.83)$ & $(0.97)$ & $(1.39)$ & $(0.46)$ \\
& -0.127 & $-0.152^{*}$ & $-0.213 * *$ & -0.140 & 0.001 \\
\hline Sector dummy (SIC-2) & Yes & $(-1.86)$ & $(-2.23)$ & $(-1.33)$ & $(0.02)$ \\
Time dummy (year) & Yes & Yes & Yes & Yes & Yes \\
\hline Observations & 150 & 150 & Yes & Yes & Yes \\
R-squared & 0.487 & 0.485 & 0.564 & 0.577 & 150 \\
$*$ ** and *** denotes significance at levels of $10 \%, 5 \%$ and $1 \%$ (for two-tailed tests), respectively. & 0.536 \\
\hline
\end{tabular}

In terms of company characteristics, larger companies in terms of total assets imply higher levels of leverage in the first five years after the IPO. Companies with a higher level of fixed assets have higher levels of leverage in the medium term, that is, from the third to the fifth year after the IPO.

These results are consistent with Myers and Majluf (1984), which show that the reduction of information asymmetry, can influence various aspects of the company's financial policy. Since PE/VC funds play an important role in transmitting the intrinsic value of invested companies to the financial market, they tend to reduce the degree of information asymmetry. In addition, companies financed by $\mathrm{PE} / \mathrm{VC}$ may be more likely to issue shares, since the exit of these funds is in part via IPO. Carvalho et al. (2013) show that $25 \%$ of exits from PE/VC funds between 2004 and 2009 were through IPO. Carvalho, Pinheiro and Sampaio (2015) also found evidence that US companies funded by PE/VC are associated with a lower level of leverage for at least 8 years after the IPO.

The lower level of leverage of the companies invested by PE/VC in Brazil may be related to economic aspects. One aspect of the Brazilian economy that inhibits investments in private equity is the low availability of credit and the reduced possibility of leverage. Private 
equity funds in the US, especially those specializing in Leverage Buy Outs, work with high leverage ratios that can reach 4 USD in debt for every dollar invested (SCHIFRIN, 1998). In Brazil, the scarce availability of resources and the cost of credit operations imply a reduced participation of debt in the capital structure of companies in which PE/VC funds invest.

\subsection{RoA}

Companies invested by PE/VC funds are younger and have significant growth potential. Table 5 shows that these companies are more profitable compared to companies not invested by PE/VC, in the first 3 years after the IPO. In terms of characteristics of the company, companies with higher sales growth, tend to present a higher level of profitability - measured by ROA.

Table 5. ROA

The dependent variable is ROA from year 1 to year 5 after the IPO. The robust $\mathrm{t}$ (or $\mathrm{z}$ ) statistics on heteroscedasticity by White's (1980) method of correction are presented in parentheses.

\begin{tabular}{lccccc}
\hline Year & 1 & 2 & 3 & 4 & 5 \\
VC dummy & $0.788^{* * *}$ & $0.730^{* * *}$ & $0.533^{* *}$ & 0.365 & 0.310 \\
& $(2.91)$ & $(3.25)$ & $(2.09)$ & $(1.51)$ & $(1.24)$ \\
Net & -0.000 & -0.000 & 0.000 & -0.001 & $0.039^{*}$ \\
Fixed Assets & $(-0.65)$ & $(-0.56)$ & $(0.01)$ & $(-0.44)$ & $(1.88)$ \\
Size & -0.013 & -0.033 & -0.020 & 0.006 & -0.053 \\
& $(-0.22)$ & $(-0.76)$ & $(-0.44)$ & $(0.12)$ & $(-1.10)$ \\
Sales & $0.073^{*}$ & $0.529^{* *}$ & $0.875^{* *}$ & $0.665^{* *}$ & $0.410^{*}$ \\
Growth & $(1.72)$ & $(2.10)$ & $(2.43)$ & $(2.15)$ & $(1.79)$ \\
Earnings & $0.001^{* * *}$ & $0.013^{* * *}$ & $0.011^{* * *}$ & $0.001^{* * *}$ & $0.001^{* * *}$ \\
Management & $(5.08)$ & $(4.32)$ & $(5.18)$ & $(8.51)$ & $(4.96)$ \\
Technology Sector & -0.351 & 0.049 & -0.120 & -0.010 & 0.050 \\
& $(-1.46)$ & $(0.41)$ & $(-0.65)$ & $(-0.04)$ & $(0.24)$ \\
IFRS dummy & -0.213 & -0.152 & 0.014 & -0.119 & -0.121 \\
& $(-1.21)$ & $(-0.99)$ & $(0.07)$ & $(-0.83)$ & $(-0.76)$ \\
\hline Sector dummy (SIC-2) & Yes & Yes & Yes & Yes & Yes \\
Time dummy (year) & Yes & Yes & Yes & Yes & Yes \\
\hline Observations & 150 & 150 & 150 & 150 & 150 \\
R-squared & 0.096 & 0.131 & 0.145 & 0.164 & 0.192 \\
\hline
\end{tabular}

${ }^{*},{ }^{* *}$ and ${ }^{* * *}$ denotes significance at levels of $10 \%, 5 \%$ and $1 \%$ (for two-tailed tests), respectively.

This result is consistent with Morsfield and Tan (2006), in which they argue that companies selected for investments in $\mathrm{PE} / \mathrm{VC}$ funds may have, on average, better performance than the rest.

Caselli (2009) analyzed 804 investments made by 87 channels of Investments of $58 \mathrm{PE} /$ VC Management Organizations in Italy in the period of $1999-2005$ and divested not before 2007. The results found indicated an average IRR of $33.17 \%$ in their study and point out that the highest returns are obtained through the Buyouts stage. The investment in PE/ VC surpassed the stock market (17.95\%) - in that sample period of poor performance of the stock market - at almost double the profitability and returned four times the government bonds -2 years government bonds. The author also concluded that the IRR is driven by sales growth, return on assets (ROA) and return on equity (ROE).

The higher levels of return on assets of companies invested by PE/VC may be related to the fact that these funds participate actively in the management of these companies. In 
BBR 16,1

general, $\mathrm{PE} / \mathrm{VC}$ funds have seats on boards of directors and are also active managers in the operations of investees. The objective of the active participation of these funds is to improve the operational efficiency and the management of these companies.

\subsection{Sales GrowTH}

Similar to the results found for the ROA variable, the variable sales growth indicates that companies invested by $\mathrm{PE} / \mathrm{VC}$ funds present superior performance to those not invested in the short term. In other words, in the first 3 years after the IPO, these companies have a higher level of sales compared to those that did not receive PE/VC investments.

The companies invested by PE/VC are companies that are in the stage of expansion; therefore, they tend to present higher rates of sales growth. The growth of investees can take place in two different ways: i) through organic growth, mainly related to the expansion of its revenues; ii) through acquisitions and mergers. It is important to note that both forms of growth tend to have an impact on the sales levels of investees, which due to the stage of expansion, seek to increase their market share.

The results are consistent with Puri and Zarutskie (2012), in which they report that companies financed by PE/VC, grow faster in terms of sales compared to non-financed companies. This result is persistent especially in the early years, before stabilization of growth.

Paglia and Harjoto (2014) also show that PE/VC financed companies have a positive impact on sales growth. The authors state that this result persists for three consecutive years after funding. The results were also consistent with Chemmanur et al. (2011), which show a positive relationship between the companies invested by $\mathrm{PE} / \mathrm{VC}$ and sales growth.

\subsection{RobUSTNESS}

The purpose of this study is to analyze the relationship between financial policies and operational performance between companies financed and non-financed by $\mathrm{PE} / \mathrm{VC}$, and its

Table 6. Sales Growth

The dependent variable is the Sales Growth of year 1 to year 5 after the IPO. The robust $\mathrm{t}$ (or z) statistics on heteroscedasticity by White's (1980) method of correction are presented in parentheses.

\begin{tabular}{|c|c|c|c|c|c|}
\hline Year & 1 & 2 & 3 & 4 & 5 \\
\hline \multirow[t]{2}{*}{ VC dummy } & $0.075^{* *}$ & $0.039 *$ & $0.093 * *$ & 0.001 & 0.024 \\
\hline & $(2.56)$ & $(1.71)$ & $(2.16)$ & $(0.02)$ & $(0.60)$ \\
\hline Net & -0.000 & -0.000 & 0.001 & 0.000 & -0.002 \\
\hline Fixed Assets & $(-0.39)$ & $(-1.14)$ & (1.63) & $(0.50)$ & $(-1.23)$ \\
\hline \multirow[t]{2}{*}{ Size } & 0.008 & 0.002 & 0.011 & -0.008 & 0.014 \\
\hline & $(0.98)$ & $(0.25)$ & $(1.07)$ & $(-0.93)$ & $(1.58)$ \\
\hline Sales & -0.001 & 0.001 & 0.013 & $0.001 * * *$ & $0.001 *$ \\
\hline Growth & $(-1.15)$ & $(1.25)$ & $(0.30)$ & (2.69) & $(1.68)$ \\
\hline Earnings & $0.077 * * *$ & $0.088 * *$ & $0.031 * *$ & $0.124 * * *$ & $0.032 *$ \\
\hline Management & $(2.94)$ & $(2.45)$ & $(1.97)$ & $(3.43)$ & (1.72) \\
\hline \multirow[t]{2}{*}{ Technology Sector } & -0.015 & 0.002 & -0.025 & 0.029 & -0.040 \\
\hline & $(-0.53)$ & $(0.09)$ & $(-0.66)$ & $(0.68)$ & $(-1.14)$ \\
\hline \multirow[t]{2}{*}{ IFRS dummy } & Yes & Yes & Yes & Yes & Yes \\
\hline & Yes & Yes & Yes & Yes & Yes \\
\hline Sector dummy (SIC-2) & 150 & 150 & 150 & 150 & 150 \\
\hline Time dummy (year) & 0.135 & 0.154 & 0.165 & 0.192 & 0.214 \\
\hline
\end{tabular}

${ }^{*},{ }^{* *}$ and ${ }^{* * *}$ denotes significance at levels of $10 \%, 5 \%$ and $1 \%$ (for two-tailed tests), respectively. 
persistence over time. In an ideal experiment, it would be possible to observe the financial policy of companies financed by $\mathrm{PE} / \mathrm{VC}$ and the financial policy that these same companies would experience if the capital contribution of $\mathrm{PE} / \mathrm{VC}$ funds was not received. This would allow us to make causal inferences about the effect of the capital contribution of PE/VC funds on the financial policy of companies. Unfortunately, given the non-experimental nature of the data, what is really possible to observe is the financial policy of the companies financed and non-financed by PE/VC. In this case, the problem is that the PE/VC investment is not distributed randomly, introducing a selection bias, which can generate complications in cases of inferences.

To reduce this bias, we used a methodology similar to Lee and Wahal (2004), in which it endogenizes the receipt of capital contribution by PE/VC funds and does not impose linearity and even restrictions in the functional form. In this sense, each company financed by $\mathrm{PE} / \mathrm{VC}$ must be combined with one or more companies not financed by PE/VC considering the same two-digit SIC code and that are similar in relation to company size, measured by total assets. In addressing this issue of endogeneity, caused by the selection effect that may exist when choosing the investments of $\mathrm{PE} / \mathrm{VC}$ funds, we can observe that the results are similar to the results presented in this study.

Table 7 presents the results for the difference in financial policies and operational performance of companies financed and not financed by PE/VC. Each funded company was combined with one or more non-funded companies using the Propensity Matching Score (PMS). The estimators, in this structure, establish a comparison between companies financed and not financed by PE/VC that are similar in terms of observable characteristics, such as industry and size. We performed the PMS considering all companies invested by PE/ $\mathrm{VC}$, where for each of them we use as counterfactual, being a single non-invested company, following Almeida et al. (2011). We also followed the recommendation by Roberts and Whited (2013), for which we applied the substitution of the correspondence procedure. After the correspondence procedure, there were 40 invested companies and 40 control companies (not invested by PE/VC)".

\section{Table 7. Univariate analysis using Propensity Matching Score}

For each IPO of a company invested by PE/VC a matching was made with one or more IPOs of companies not invested by PE/VC using 2-Digits SIC and size based on the total value of the assets as an instrumental variable in each matching .

\begin{tabular}{lccccc}
\hline & 1 & 2 & 3 & 4 & 5 \\
\hline Cash & 0.165 & 0.231 & 0.272 & 0.341 & 0.363 \\
& $(2.20)^{* *}$ & $(2.98)^{* * *}$ & $(3.34)^{* * *}$ & $(3.46)^{* * *}$ & $(3.70)^{* * *}$ \\
\hline Leverage & -0.313 & -0.325 & -0.342 & -0.331 & -0.315 \\
& $(2.23)^{* *}$ & $(2.21)^{* *}$ & $(2.07)^{* *}$ & $(2.13)^{* *}$ & $(2.19)^{* *}$ \\
\hline ROA & & & & 0.210 \\
& 0.732 & 0.620 & 0.531 & 0.235 & $(1.12)$ \\
\hline Sales Growth & $(3.12)^{* * *}$ & $(3.13)^{* * *}$ & $(2.02)^{* *}$ & $(1.20)$ & \\
& & & & & \\
& 0.037 & 0.031 & 0.025 & 0.022 & $(1.04)$ \\
\hline
\end{tabular}

\footnotetext{
${ }^{*},{ }^{* *}$ and ${ }^{* * *}$ denotes significance at levels of $10 \%, 5 \%$ and $1 \%$ (for two-tailed tests), respectively.
} 
BBR

16,1

99

\section{CONCLUSION}

In this article, we analyze the role of $\mathrm{PE} / \mathrm{VC}$ funds in terms of the financial policy of companies and their persistence (fixed effects of these companies) over time. To perform this analysis, we used four variables to measure the operational and financial performance of these companies. In terms of capital structure, we used the variable of leverage and cash $\&$ equivalents. In terms of operational performance, we used the variable of return on assets, as measured by ROA, and sales growth, as measured by the variation in net revenues of the companies analyzed.

The main conclusion is that the common origin of a company leads to similarities in its financing policies and financial performance even in a medium period, in this case, 5 years after the IPO. The results indicated that companies that received capital contributions from $\mathrm{PE} / \mathrm{VC}$ chose a different set of policies than those not financed.

In addition, companies financed by PE/VC imply a higher level of cash and cash \& equivalents in relation to non-financed ones. This effect is permanent for at least 5 years after the IPO. We also emphasize that companies financed by PE/VC are associated with a lower level of leverage in the first 5 years after the IPO. In terms of profitability, the results indicated that these companies perform better, as measured by ROA, in the first 3 years after the IPO. These companies also presented a superior result when considering sales growth as a variable of operational performance.

In order to reduce the recurring problem of selection bias that occurs in studies related to PE/VC investments, this study used a similar methodology to Lee and Wahal (2004). The results found based on the model of Propensity Score Matching were similar to those already found in the multivariate regressions. These results gave more robustness to the evidence found in this study. However, it is important to emphasize that this method does not eliminate the endogeneity problem that exists in the investments made by PE/VC funds. Therefore, the results presented are indicative of the relationships between these financial variables and the investments made by the PE/VC funds. For a better understanding of these effects, future studies are needed.

\section{BIBLIOGRAPHIC REFERENCES}

ALMEIDA, H., CAMPELLO, M, LARANJEIRA, B., and WEISBENNER, S. (2011). Corporate Debt Maturity and the Real Effects of the 2007 Credit Crisis. Critical Financial Review, v.1, p.3-58.

ARAÚJO, C. (1996). A Política de Dividendos das Empresas Brasileiras: Empresas vs Acionistas. Centro de Ciências Jurídicas e Econômicas - Instituto de Pós-Graduação e Pesquisa em Administração COPEAD. Available at: < http://www.coppead.ufrj.br/upload/publicacoes/Claudia_Araujo.pdf >.

BARRY, C. B.; MUSCARELLA, C. J.; PEAVY III, J. W.; VETSUYPENS, M. R. (1990). The role of venture capital in the creation of public companies: evidence from going-public process. Journal of Financial Economics, v. 27, p. 447-471.

BRASIL. Lei 6.404, de 15 de dezembro de 1976. Dispõe sobre as Sociedades por Ações. Available at: <http:// www.planalto.gov.br>. Access in: March 05, 2018.

BRAV, A.; GOMPERS, P. A. (1997). Myth or reality? The long-run underperformance of initial public offerings: evidence from venture and non venture capital-backed companies. Journal of Finance, v. 52, (5), p. 1791-1821.

CARPENTER, M. A.; POLLOCK, T. G.; LEARY, M. M. (2003). Testing a model of reasoned risk-taking: governance, the experience of principals and agents, and global strategy in high-technology IPO firms. Strategy Manage Journal, v. 24, p. 803-820.

CARVAlHO, A. G.; NETTO, H. G.; SAMPAIO, J. O. (2013). Private Equity and Venture Capital in Brazil: An Analysis of its Recent Evolution. Available at SSRN: http://papers.ssrn.com/sol3/papers.cfm?abstract id=1996729. 
CARVALHO, A. G.; PINHEIRO, R. B.; SAMPAIO, J. O. (2015). Venture Capital Backing: Operational Performance and Persistence Over Time. Working paper.

CASELli, S.; GARCIA A., E.; IPPOLITO, F. (2009). Explaining Returns in Private Equity Investments, Working Paper, n.15/09, Milan, Carefin Bocconi, [Online] Available at: <http://papers.ssrn.com/sol3/papers.cfm?abstract_id=1600227>

CHEMMANUR, T. J.; KRISHNAN, K.; NANDY, D. K. (2011). How Does Venture Capital Financing Improve Efficiency in Private Firms? A Look Beneath the Surface. Review of Financial Studies, v. 24, (12), p. 4037-4090.

CHEN, Y. R.; CHUANG, W. T. Alignment or entrenchment? Corporate governance and cash holdings in growing firms. Journal of Business Research, v. 62, (11), p. 1200-1206.

CRONQVIST, H.; LOW, A.; NILSSON, M. (2009). Persistence in Firm Policies, Firm Origin, and Corporate Culture: Evidence from Corporate Spin-offs. Robert Day School of Economics and Finance. Working Paper No. 2009-2.

DEANGELO, H.; DEANGELO, L. (2006). The Irrelevance of the MM Dividend Irrelevance Theorem. Journal of Financial Economics, v. 79, 293-315.

DECHOW, P. M.; SLOAN, R. G.; SWEENEY, A. P. (1995). Detecting earnings management. The Accounting Review, Nova York, v. 70, n. 2, p. 193.

FRIED, V. H.; BRUTON, G. D.; HISRICH, R. D. (1998). Strategy and the board of directors in venture capital-backed firms. Journal of Business Venturing, v. 13, p. 493-503.

GOMPERS, P.; LERNER J. (1999). The venture capital cycle. Cambridge, MA: The MIT Press.

(2), p. 145-168.

. (2001). The venture capital revolution. Journal of Economic Perspectives, 15,

HELLMANN, T.; PURI, M. (2002). Venture capital and the professionalization of start-up firms: empirical evidence. Journal of Finance, v. 57, (1), p. 169-197.

HERMALIN, B. E. (2001). Economics and Corporate Culture in Cary L. Cooper, Sue Cartwright and P. Christopher Earley, eds.: The International Handbook of Organizational Culture and Climate, England: John Wiley \& Sons.

JAIN, B. A.; SHEKHAR, C.; TORBEY, V. (2009). Payout initiation by IPO firms: The choice between dividends and share repurchases. The Quarterly Review of Economics and Finance, v. 49, p. 1275-1297.

KAPLAN, S. N.; STROMBERG, P. (2003). Financial contracting theory meets the real world: na empirical analysis of venture capital contracts. Review of Economic Studies, v. 70, (2), p. 281-315.

KREPS, D. M. (1990). Corporate Culture and Economic Theory in J. E. Alt and K. A. Shepsle, eds.: Perspectives on Positive Political Economy, Cambridge, England: Cambridge University Press.

LEE, P. M.; WAHAL, S. (2004). Grandstanding, certification and the underpricing of venture capital backed IPOs. Journal of Financial Economics, v. 73, (2), p. 375-407.

LERNER, J. (1994). Venture capitalists and the decision to go public. Journal of Financial Economics, v. 35, p. 293-316.

LOUGHRAN, T.; RITTER, J. R. (2002). Why don't issuers get upset about leaving money on the table in IPOs? The Review of Financial Studies, v. 15, (2), p. 413-443.

MINARDI, A. M. A. F.; KANITZ, R. V.; BASSANI, R. H. (2014). Private Equity and Venture Capital Industry Performance in Brazil: 1990-2013. The Journal of Private Equity, v. 17, (4), p. 48-58.

MORSFIELD, S. G.; TAN, C. E. L. (2006). Do venture capitalists influence the decision to manage earnings in initial public offerings? Accounting Review, v. 81, (5), p. 1119-1150.

MYERS, S.; MAJLUF, N. (1984). Corporate Financing and Investment Decisions when firms have information that Investors do not have. Journal of Financial Economics, v. 13, p. 187-221.

PAGLIA, J. K.; HARJOTO, M. A. (2014). The effects of private equity and venture capital on sales and employment growth in small and medium-sized businesses. Journal of Banking \& Finance, v. 47, p. 177-197.

PHILLIPS, B. D. (1991). The increasing role of small firms in the high-technology sector: evidence from the 1980s. Business and Economics, v. 26, (1), p. 40-47.

PURI, M.; ZARUTSKIE, R. (2012). On the Life Cycle Dynamics of Venture-Capital- and Non-VentureCapital-Financed Firms. The Journal of Finance, v. 67, (6), p. 2247-2293.

ROBERTS, M., WHITED, T.M. (2013). Endogeneity in Empirical Corporate Finance. Handbook of the Economics of Finance, v. 42, (5), p. 493-572 
BBR

\section{6,1}

101

SAHLMAN, W.A. (1990). The structure and governance of venture capital organizations. Jornal of Financial Economics, v. 27, (2), 473-521.

SCHIFRIN, M. (1998). LBO madness. Forbes, 161(5), 128-134.

SIQUEIRA, E. M. R.; CARVALHO, A. G.; NETTO, H. G. (2011). Determinantes do sucesso dos investimentos de Private Equity e Venture Capital no Brasil. Revista Brasileira de Finanças, v. 9, (2), p. 189-2008.

VAN DEN BERGHE, L. A. A.; LEVRAU, A. (2002). The role of the venture capitalist as monitor of the company: a corporate governance perspective. Corporate Governance International Review, v. 10, (3), p. 124-135.

WHITE, H. (1980). A heteroskedasticity-consistent covariance matrix estimator and a direct test of heteroskedasticity. Econometrica, v. 48, (4), p. 817-838. 